\title{
Depression, Anxiety, Stress, and Adjustments among Malaysian Gifted Learners: Implication towards School Counseling Provision
}

\author{
Abu Yazid Abu Bakar ${ }^{1} \&$ Noriah Mohd Ishak ${ }^{2}$ \\ ${ }^{1}$ Faculty of Education, Universiti Kebangsaan Malaysia, Bangi, Selangor, Malaysia \\ ${ }^{2}$ Pusat PERMATApintar ${ }^{\mathrm{TM}}$ Negara, Universiti Kebangsaan Malaysia, Bangi, Selangor, Malaysia \\ Correspondence: Abu Yazid Abu Bakar, Faculty of Education, Universiti Kebangsaan Malaysia, 43600 Bangi, \\ Selangor, Malaysia. Tel: 603-8921-7697.E-mail: yazid3338@ukm.edu.my
}

Received: July 22, 2014 Accepted: November 5, 2014 Online Published: December 21, 2014

doi:10.5539/ies.v7n13p6 URL: http://dx.doi.org/10.5539/ies.v7n13p6

\begin{abstract}
Gifted learners have special characteristics which make them unique individuals. However, just like their normative group, gifted learners experience some psychological issues that hinder their ability to adjust in new environments. This study aims to examine levels of depression, anxiety, stress, and adjustments (psychological, social and emotional) faced by Malaysian gifted learners in school. It also investigates the relationship between all these variables under study. A total of 112 students aged 16 years old were involved in the study. The study employs a cross-sectional survey design, and the data was collected using two sets of questionnaires namely, the Depression, Anxiety, and Stress Scales (DASS), and the Social Well-Being Questionnaire (SWBQ). Data shows that local gifted learners experienced some form of depression, anxiety and stress. It is also found that the participants have high levels of psychological, social and emotional adjustments. Strong positive correlations were found between depression with anxiety and stress, whereas negative correlation was found between depressions with all forms of adjustment. The findings of this research provided a fundamental basis to be used in the future development of counseling provision for gifted educational programs in local school context.
\end{abstract}

Keywords: adjustment, anxiety, counseling, depression, gifted, stress

\section{Introduction}

\subsection{Gifted Learners}

Gifted learners have special characteristics that make them unique individuals. Typically they have been identified as having superior linguistic abilities, a distinct capacity to understand and explain complex concepts on a variety of topics, and to develop expertise in a particular area or topic, all of which that reflects a maturity beyond their years (Nielsen, 2002; Assouline, Nicpon, \& Whiteman, 2010; Sattler, 2008). They are also said to be divergent thinkers, very creative, and possess a sophisticated sense of humor (Baum \& Owen, 1988; Nielsen, 2002). According to Neihart, Robinson, and Moon (2002), gifted learners are as diverse in temperament, have risk taking behaviors, display significant degrees of assertiveness, and invest greater effort in moving towards achieving their goals, as compared to their normal counterparts. As such, it is impossible to observe any standard patterns of talents and characteristics among these gifted individuals.

Nonetheless, despite variability in personalities, there exist several common social and emotional characteristics among gifted learners that call for special attention (Neihart et al., 2002). These social and emotional characteristics have long been known to be associated with the need to excel intellectually or academically (Becker \& Luthar, 2002; Robinson, 2004). It is also linked to parental and societal expectations of good academic standing among gifted learners. According to Neihart et al. (2002) and Robinson (2004), gifted learners experience a sense of frustration when their ability to cope with the demands falls below expectation. They also tend towards self-doubt which impacts negatively on self-confidence, peer relationships, capacity for adjustment and self-concept (Brody \& Benbow, 1986). Since they are not accustomed to failure, these feelings and frustration may cause psychological disturbances such as depression, anxiety and stress among gifted learners. It becomes crucial to deal with these issues amongst gifted learners in a timely and effective manner.

Studies conducted by Sands and Howard-Hamilton (1995), and Hayes and Sloat (1989) found that depression is a problem that is not uncommon among learners or adolescents who are identified as gifted and talented. In 
addition, a study conducted by De Moss, Milich, and DeMers (1993) shows high achieving adolescents who are also identified as gifted are at significant risk for depression. A study conducted by Metha and McWirther (1997) shows that when under duress the mixed-ethnic samples under the study displayed signs of depression and suicide. On a similar note, an earlier study conducted by Beer (1991) established high positive correlation between depression and anxiety among gifted learners. They also have significantly higher levels of anxiety when compared to regular students (Tong \& Yewchuk, 1996). Other studies have also shown that gifted learners are constantly challenged with more affective and psychological issues than their normal counterparts (Neihart et al., 2002; Rimm, 2002; Baker, 1995; Bailey, 2007).

Regardless of the type of psychological problems (depression, anxiety or stress), studies have shown that when the level of the problems are high, gifted learners experienced negative feelings that leads to issues in psychological, emotional and social adjustments. Studies conducted by Gallucci (1988), and Nail and Evans (1997) show that although gifted learners showed fewer indicators of maladjustment, they are at-risk for more social and emotional difficulties than are moderately non-gifted students. According to Coleman and Cross (1988), and Swiatek (1995), peer relations and social competence are two factors that are frequently associated with social adjustment. Some studies show that gifted learners are more prone to a more advanced level of social adjustment issues (Galloway \& Porath, 1997; Dauber \& Benbow, 1990; Neihart et al., 2002). Other studies have also shown that certain subgroups of gifted learners have more difficulties in adjusting socially, and their attitudes towards learning and peer relationships became less positive as they became older. A more recent and localized study conducted by Abu Yazid and Noriah (2012) on Malaysian gifted learners also shows that the students faced psychological problems that need timely attention. However, this study did not examine the relationship between the psychological problems faced by the students and their adjustment ability. As such, this study was designed to further examine the relationship between depression, anxiety and stress faced by the Malaysian gifted learners studying at Pusat PERMATApintar ${ }^{\mathrm{TM}}$ Negara, Universiti Kebangsaan Malaysia (the Malaysian National Gifted Center established at the National University of Malaysia), and their ability to adjust psychologically, emotionally and socially.

\subsection{Depression, Anxiety and Stress}

Depression is defined as a mood or emotional state that is marked by feelings of low self-worth or guilt and a reduced ability to enjoy life. It is an illness that involves the body, mood and thought that affects the way a person does ordinary activities (Gardner \& Bell, 2000). Depressed people usually exhibit symptoms such as sadness, hopelessness, low self-esteem, decreased ability to take pleasure in ordinary activities, loss of appetite, thoughts of death or suicide attempts and insomnia. In addition, depressed sufferers also experience irritability, apathy, forgetfulness, suicidal thoughts, confusion, lethargy, detachment, and are prone to sleep too little or too much.

In contrast, Gardner and Bell (2000) defined anxiety as a strong and unpleasant feeling of nervousness or distress in response to a feared situation. Anxiety is also a multisystem response. It usually occurs when a person is in a flight or fight situation and it reflects a combination of biochemical changes in the body. Some symptoms of anxiety are nausea, trembling, breathlessness, sweating, and a rapid heartbeat.

Stress, is a term coined by an endocrinologist, Selye (1978), which he depicted as a non-specific response of the body to any demand placed upon an individual. Holmes and Rahe (1967) described stress in two ways; distress that is caused by negative situations, and eustress which is caused by positive situations. Stress is also defined as the body's general response to any intense physical, emotional, or mental demand placed by one or others. While racing to meet a deadline, dealing with a difficult person, or earning a poor grade are all stressful, so is the excitement of playing a lively game of tennis, falling in love, and being selected to join a special program for gifted students. This is eustress or positive stress that motivates one to progress and succeed in life.

There are few studies on stress which support the notion that gifted learners experience different kinds of stress, such as unrealistic expectations of their parents and overwhelming expectations of their teachers (Chan, 2003; Kaufman, 1992). A specific stress comes from being labeled as gifted, further defined by the selective learning environments of these students. Identifying stressors and the type of reaction to stressors will help counselors to take measures to address issues and improve the psychological health and well-being of the students (Yewchuk \& Jobagy, 1991; Coleman \& Cross, 1988; Delisle, 1985; Galbraith, 1985). There are three sources of stress for gifted learners. The sources can be situational, self-imposed and existential (Swiatek, 2001). Situational stress is conflict between one's own values and the values of others, interpersonal disharmony, a lack of intellectual stimulation or challenge, threats to emotional or physical well-being, a lack of resources to accomplish a task and time constraints. Self-imposed stress is the setting of excessively high expectations, fear of failure or fear of 
success, unsettling evaluative beliefs, catastrophizing, intense worry and negative intrapersonal communication. Existential stresses are related to global concerns, idealism, anger at fate, isolation and the need for meaning and purpose (Shaunessy \& Suldo, 2010). Despite the sources of stress, gifted learners have to adapt and adjust accordingly to realize and achieve their potential. Only then their innate ability, referred as the gift, can be transformed to talent (Sternberg \& Davidson, 2005).

\subsection{Psychological, Emotional and Social Adjustments}

Psychological adjustment is the mental response of a person to varying sources of discomfort in real life situations. A person is psychologically adjusted when he or she feels a sense of happiness or contentment in life. It is also referred to as a positive mental state and generally being able to experience happiness or satisfaction. Psychological adjustment is needed when one needs to balance between his or her various needs and the demands made by elements within their environment. A sequence of adjustment begins when a need is felt and ends when the need is satisfied. According to Parker (1996), gifted learners experience high environmental demands. Contrary to the myths about gifted learners' inability to adjust psychologically, his study shows that gifted learners are significantly better in psychological adjustment when compared to the adolescents' normative group. In contrast, social adjustment is a sense of involvement with other people and with communities. It is an indicator that measures how people experience their connections with others and the strength of those relationships. For gifted learners, their social preferences are similar to those of older children and adults. This is because they have less interest in children of lower mental maturity and choose friends among children of similar levels of interest and ability. They relate well to adults and may have problems playing with playmates of similar chronological age with normal interests and abilities (Davis \& Rimm, 2004; Freeman, 1994). Emotional adjustment, on the other hand, is the change in the intensity of feelings, complex emotions, and a difficulty in adjusting to change (Dabrowski, 1973; Piechowski, cited in Silverman, 1993). In general, gifted learners show better emotional adjustment than their normal counterparts, although some studies indicate a closer relationship to socioeconomic differences than to intellectual differences (Oram, Dewey, \& Rutemiller, 1995). According to Piechowski (1991), gifted learners have a very high energy level, which can result in emotional excitability, high sensitivity, rapid and compulsive verbalization, abundant imagination, and emotional reactions that can be extremely elevated or depressed.

Gifted learners' adjustment level is higher than their non-gifted peers. Their cognitive abilities allow gifted learners to have a better understanding of the self, environment and other people. As such they cope well with stress. A longitudinal study conducted by Terman $(1925)$ and Terman and Oden $(1935,1947)$ shows that gifted individuals display lower incidence of mental illness and adjustment problems. When compared with non-gifted individuals, they are less vulnerable to mental disorders (Coleman \& Fults, 1985). However, past studies have also shown that gifted learners have difficulties in educational and social adjustments (Hollingworth, 1942; Tannenbaum, 1983; Gross, 1993; Galluci, 1988; Janos, Fung, \& Robinson, 1985; Janos \& Robinson, 1985; Yewchuck \& Jobagy, 1991). Concomitantly, researchers have not come to a consensus on the patterns of adjustment displayed by gifted learners. As such, it is timely that this study examines not only the adjustment issues of the gifted learners but also the relationship between depression, anxiety and stress towards psychological, social and emotional adjustments among gifted learners. Findings from such a study could deepen our understanding on psychological issues that hinders gifted learners' academic performance, as well as their personal well-being. Specifically, this study examined: (a) levels of depression, anxiety and stress among the gifted learners, (b) levels of psychological, social and emotional adjustments among the gifted learners, and (c) the relationship between depression, anxiety, and stress and psychological, social and emotional adjustments.

\section{Methodology}

\subsection{Research Location}

The study was conducted at Pusat PERMATApintar ${ }^{\mathrm{TM}}$ Negara, the Malaysia National Gifted Center set up at Universiti Kebangsaan Malaysia. The center-which was established in 2009-offers activities inclusive of identifying and selecting gifted students through two online systems developed by the University, a 3-week school holiday program conducted annually in collaboration with Johns Hopkins University-Center for Talented Youth (JHU-CTY), and a high school two-year residential program for gifted students aged between 14-17 years old. The residential school program offers a comprehensive academic curriculum (equivalent to ' $\mathrm{O}$ ' and ' $\mathrm{A}$ ' Levels of the UK system), a mentoring research program, and co-curriculum activities that involve projects and voluntary services. The center also offers a pre-university program as a pathway to commence tertiary studies at the University. 


\subsection{Research Participant}

The first cohort of PERMATApintar ${ }^{\text {TM }}$ residential school's students aged 16 years old, were selected for this study. The sample comprised of 112 gifted learners with a total of 77 female students and 35 male students.

\subsection{Measures, Data Collection, and Data Analysis}

Research participants were given two sets of questionnaires: (a) Depression, Anxiety and Stress Scales (DASS), and (b) Social Well-Being Questionnaire (SWBQ). The DASS has 42 items that measures depression, anxiety and stress level of the students. The SWBQ has seven sections and it is used to determine the psychological, social and emotional adjustment of the students. Data collected from both instruments were inferentially and descriptively analyzed using Statistical Package for Social Sciences (SPSS) software version 18.0.

\section{Results}

Table 1 shows levels of depression, anxiety and stress experienced by the participants. The range level for depression is from 0.00 and 76.19. The range level for stress is between 2.22 and 88.89 and the range level for anxiety is between 0.00 and 79.49. Stress has the highest mean (Mean $=33.75, \mathrm{SD}=16.68$ ), followed by anxiety $($ Mean $=33.16, \mathrm{SD}=15.88)$, and depression $(\mathrm{Mean}=24.91, \mathrm{SD}=17.25)$. Nonetheless, all means are considered at the lower end of the continuum.

Table 1. Participants' levels of depression, anxiety, and stress

\begin{tabular}{lccccc}
\hline & $\mathrm{N}$ & Minimum & Maximum & Mean & Std. Deviation \\
\hline Depression & 112 & 0.00 & 76.19 & 24.91 & 17.25 \\
Anxiety & 112 & 0.00 & 79.49 & 33.16 & 15.88 \\
Stress & 112 & 2.22 & 88.89 & 33.75 & 16.68 \\
\hline
\end{tabular}

The three aspects of adjustments (psychological, social, and emotional) were also examined. The range level for psychological adjustment is between 41.94 and 104.52, the range level for emotional adjustment is between 31.25 and 117.50, and the range level for social adjustment is between 46.50 and 93.50. Emotional adjustment has the highest mean (Mean $=79.82, \mathrm{SD}=9.92)$, followed by psychological adjustment $($ Mean $=77.07, \mathrm{SD}=$ 8.87 ), and social adjustment (Mean $=71.94, \mathrm{SD}=8.78$ ). Nonetheless, all means are considered at the higher end of the continuum (Table 2).

Table 2. Participants' levels of adjustment

\begin{tabular}{lccccc}
\hline Types of Adjustment & $\mathrm{N}$ & Minimum & Maximum & Mean & Std. Deviation \\
\hline Psychological & 112 & 41.94 & 104.52 & 77.07 & 8.47 \\
Emotional & 112 & 31.25 & 117.50 & 79.82 & 9.92 \\
Social & 112 & 46.50 & 93.50 & 71.94 & 8.78 \\
\hline
\end{tabular}

Relationships between depression with anxiety, stress, and the three types of adjustments (psychological, social and emotional) were also examined using Pearson Product-Moment Correlation Coefficient. Table 3 shows the correlation ( $r$ ) values for all correlations. The $r$ values between depression and stress $\left(r=.67, r^{2}=0.45, p<0.05\right)$, and between depression and anxiety $\left(\mathrm{r}=.56, \mathrm{r}^{2}=0.31, \mathrm{p}<0.05\right)$ were found to be positive. The association between depression and stress is $45 \%$, while for depression and anxiety is $31 \%$. These percentages are considered high. Moreover, depression and all aspects of adjustment were found to be negatively correlated among each other. 
Table 3. Correlations between depression with anxiety, stress, and adjustments

\begin{tabular}{lllllll}
\hline & & Stress & Anxiety & Psychological & Emotional & Social \\
\hline \multirow{3}{*}{ Depression } & Pearson Correlation & $.67^{* *}$ & $.56^{* *}$ & $-.22^{*}$ & -.15 & $-.34^{* *}$ \\
& Sig. (2-tailed) & .00 & .00 & .02 & .13 & .00 \\
& $\mathrm{~N}$ & 112 & 112 & 112 & 112 & 112 \\
\hline
\end{tabular}

**Correlation is significant at the 0.05 level (2-tailed).

\section{Discussions and Conclusion}

This study has found some conclusive evidence to explain: (a) patterns of depression, anxiety and stress, (b) psychological, social and emotional adjustment, and (c) relationship between all the variables among gifted learners participated in this study. Exploration on the depression, anxiety and stress using different means of data collection shows that stress is one of the most salient psychological issues faced by research participants, followed by anxiety, and depression. In addition, depression is found to be highly correlated to stress and anxiety level, whereas it has a moderately low negative correlation with levels of psychological, social, and emotional adjustments.

In general, findings from this study show that Malaysian gifted learners experienced some depression, anxiety and stress. For instance, data gathered from this research somehow support the studies conducted by Chan (2003) and Kaufman (1992) which carry the notion that gifted learners experience different kinds of stress, such as the unrealistic expectations of their parents, and overwhelming expectations of their teachers. Parents place high hopes on their child when the child is identified as gifted and talented (Chan, 2003; Kaufman, 1992). They believe their child will be able to achieve and fulfill these high expectations as the child has been deemed 'gifted and talented'. This is an outcome of labeling and parents should be educated to the potential dangers of unrealistic demands and expectations on their child (Yewchuk \& Jobagy, 1991; Coleman \& Cross, 1988; Delisle, 1985; Galbraith, 1985). If unattended, a situation like this leads to psychological issues such as depression, stress and anxiety. Furthermore, some teachers have very high expectations of their gifted and talented students (Chan, 2003; Kaufman, 1992). It is assumed that they can think and perform beyond their average peers. Therefore, teachers tend to give less attention to gifted learners as they would to their peers. This inevitably pressures the gifted learners to be responsible for their own learning and success. Gifted learners also have difficulty in expressing and sharing their thoughts and problems with their peers. The further stress which comes from being labeled as gifted-and this being defined by their selective learning environment-makes it crucial for a counselor to identify stressors and the type of reaction to stressors. This will allow for a counselor to offer effective assistance to improve the psychological health and well-being of gifted learners (Yewchuk \& Jobagy, 1991; Coleman \& Cross, 1988; Delisle, 1985; Galbraith, 1985).

Gifted and talented learners also face interpersonal issues with their peer groups. They are generally more intellectual and academically able when compared to their average counterparts. It will be natural for non-gifted students to distance themselves from their more gifted counterparts as they will not be able to easily share nor understand some of their perspectives; hence, the social interaction will be strained (Gargiulo, 2006; Sousa, 2003). The feeling of being marginalized by the broader peer population will inevitably lead the gifted learners to sense of isolation. On some occasions, it is observed that gifted and talented learners tend to use humor either on themselves or on complex situations to help make things more tolerable, diffuse strained situations, and to be more easily accepted by their peers. These developments inevitably lead to a sense of isolation and subsequent depression among gifted learners.

Findings from the study also show that gifted learners have high psychological, emotional and social adjustment levels. When gifted and talented learners are more stable emotionally they tend to be more open and flexible thus easing their assimilation process (Gargiulo, 2006; Sousa, 2003). According to Gargiulo (2006), and Sousa (2003), gifted and talented learners adapt easily to new situations. Therefore, they can mingle well with others. However, this notion is contradicted with findings from a study conducted by Bee (1999) where learners with higher intelligence than their peers will have difficulties in adapting themselves to a new environment.

Thus, implications of this study toward the provision of school counseling in local context shall be viewed on these three main paradigms:

a. the guidance and counseling board for the introduction of intervention programs to help these students to address their psycho-socio-emotial issues 
b. the parent-teacher association (PTA) on how to help or support the student psychological well-being through parents' understanding/efforts

c. the teaching and learning pedagogical approach, teacher student relationship and curriculum related issues include assessment approach that could help reduce the depression levels among the students

In a nutshell, gifted learners have their own patterns of psychological concerns including depression, anxiety stress, and adjustment levels. If these concerns are not properly addressed, the students will experience disequilibrium in life and will not be able to realize their potential to the fullest. Therefore, it is critical for school counselors to understand these concerns in order to enable them to provide effective counseling and guidance services. In the context of Malaysian gifted learners, the inability to understand such concerns will probably causing the students to avoid seeking help from school counselors (Noriah \& Abu Yazid, 2010). In other words, other than focusing on providing academic guidance and career counseling, school counseling provision for gifted learners should also offer personal services that could act in relieving their depression, anxiety, stress, and adjustment issues.

\section{References}

Abu Yazid, A. B., \& Noriah, M. I. (2012). Profil psikologi, mekanisme strategi bela diri, dan pola keperluan kaunseling dalam kalangan pelajar pintar dan berbakat: Satu kajian kes. Journal of Special Needs Education, 2, 127-137.

Assouline, S. G., Nicpon, M. F., \& Whiteman, C. (2010). Cognitive and psychosocial characteristics of gifted students with written language disability. Gifted Child Quarterly, 54(2), 102-115. http://dx.doi.org/10.1177/0016986209355974

Bailey, C. L. (2007). Social and emotional needs of gifted students: What school counselors need to know to most effectively serve this diverse student population? Paper presented at the 2007 Association for Counselor Education and Supervision Conference, October 11-14, Columbus, Ohio.

Baker, J. A. (1995). Depression and suicide ideation among academically talented adolescents. Gifted Child Quarterly, 39(1), 218-233. http://dx.doi.org/10.1177/001698629503900405

Baum, S., \& Owen, S. V. (1988). High ability/learning disabled students: How are they different? Gifted Child Quarterly, 32(3), 321-326. http://dx.doi.org/10.1177/001698628803200305

Becker, B. E., \& Luthar, S. S. (2002). Social-emotional factors affecting achievement outcomes among disadvantaged students: Closing the achievement gap. Educational Psychologist, 37(4), 197-214. http://dx.doi.org/10.1207/S15326985EP3704_1

Bee, H. (1999). The growing child: An applied approach (2nd ed.). New York, NY: Longman.

Beer, J. (1991). Depression, general anxiety, test anxiety, and rigidity of gifted junior high and high school children. Psychological Reports, 69(3f), 1128-1130. http://dx.doi.org/10.2466/pr0.1991.69.3f.1128

Brody, L. E., \& Benbow, C. P. (1986). Social and emotional adjustment of adolescents extremely talented in verbal or mathematical reasoning. Journal of Youth and adolescence, 15(1), 1-18. http://dx.doi.org/10.1007/BF02140780

Chan, D. W. (2003). Assessing adjustment problems of gifted students in Hong Kong: The development of the Student Adjustment Problem Inventory. Gifted Child Quarterly, 47(2), 1007-118. http://dx.doi.org/10.1177/001698620304700202

Coleman, L. J., \& Cross, T. L. (1988). Is being gifted a social handicap? Journal for the Education of the Gifted, 11(4), 41-56.

Coleman, M., \& Fults, B. (1985). Special-class placement, level of intelligence, and the self-concept of gifted children: A social comparison perspective. Remedial and Special Education, 6, 7-12. http://dx.doi.org/10.1177/074193258500600103

Dabrowski, K. (1973). Psychoneurosis is not an illness: Neuroses and psychoneuroses from the perspective of positive disintegration. London, UK: Gryf Publications.

Dauber, S. L., \& Benbow, C. P. (1990). Aspects of personality and peer relations of extremely talented adolescents. Gifted Child Quarterly, 34(1), 10-14. http://dx.doi.org/10.1177/001698629003400103

Davis, G. A., \& Rimm, S. B. (2004). Education of the gifted and talented (5th ed.). Boston, MA: Allyn \& Bacon.

Delisle, J. (1985). The eight great gripes of gifted kids: Responding to special needs, Roeper Review, 8(11), 
15-17.

De Moss, K., Milich, R., \& DeMers, S. (1993). Gender, creativity, depression, and attributional style in adolescents with high academic ability. Journal of Abnormal Child Psychology, 21(4), 455-467. http://dx.doi.org/10.1007/BF01261604

Freeman, J. (1994). Some emotional aspects of being gifted. Journal for the Education of the Gifted, 17(2), 180-197. http://dx.doi.org/10.1177/016235329401700207

Galbraith, J. J. (1985). Teaching the Gifted Child. Newton, MA: Allyn and Bacon.

Galloway, B., \& Porath, M. (1997). Parent and teacher views of gifted children's social abilities. Roeper Review, 20(2), 118-121. http://dx.doi.org/10.1080/02783199709553872

Galluci, N. T. (1988). Emotional adjustment of gifted children.Gifted Child Quarterly, 32, $273-276$. http://dx.doi.org/10.1177/001698628803200206

Gardner, J., \& Bell, A. H. (2000). Overcoming anxiety, panic, and depression: New ways to regain your confidence. Franklin Lake, NJ: The Career Press Inc.

Gargiulo, R. M. (2006). Special education in contemporary society: An introduction to exceptionality (2nd ed.). Belmont, CA: Thompson Wadsworth.

Gross, M. U. M. (1993). Exceptionally gifted children. New York, NY: Routledge. http://dx.doi.org/10.4324/9780203315378

Hayes, M. L., \& Sloat, R. S. (1989). Gifted students at risk for suicide. Roeper Review, 12(2), $102-107$. http://dx.doi.org/10.1080/02783198909553245

Hollingworth, L. (1942). Children above 180 IQ. Stanford Binet, New York, NY: World Book. http://dx.doi.org/10.1037/13574-000

Holmes, T. H., \& Rahe, R. H. (1967). The social readjustment rating scale. Journal of Psychosomatic Research, 11(2), 213-218. http://dx.doi.org/10.1016/0022-3999(67)90010-4

Janos, P. M., \& Robinson, N. M. (1985). Psychological development in intellectually gifted children. In F. D. Horowitz, \& M. O’Brien (Eds), The gifted and talented: Development perspectives (pp. 149-195). Washington, DC: American Psychological Association. http://dx.doi.org/10.1037/10054-006

Janos, P. M., Fung, H. C., \& Robinson, N. (1985). Self-concept, self-esteem, and peer relations among gifted children who feel "different". Gifted Child Quarterly, 29(1), 78-81. http://dx.doi.org/10.1177/001698628502900207

Kaufman, A. S. (1992). Test reviews: Evaluation of the WISC-III and WPSI-R for gifted children. Roeper Review, 14(3), 154-158. http://dx.doi.org/10.1080/02783199209553413

Metha, A., \& McWirther, E. H. (1997). Suicide ideation, depression, and stressful life events among gifted adolescents. Journal for the Education of the Gifted, 20(3), 284-304.

Nail, J. M., \& Evans, J. G. (1997). The emotional adjustment of gifted adolescents: A view of global functioning. Roeper Review, 20(1), 18-21. http://dx.doi.org/10.1080/02783199709553845

Nielsen, M. E. (2002). Gifted students with learning disabilities: Recommendations for identification and programming. Exceptionality, 10(2), 93-111. http://dx.doi.org/10.1207/S15327035EX1002_4

Noriah, M. I., \& Abu Yazid, A. B. (2010). Counseling for gifted students: Implication for a differentiated approach. The International Journal of Learning, 17(6), 377-391.

Oram, G. D., Cornell, D. G., \& Rutemiller, L. A. (1995). Relations between academic aptitude and psychosocial adjustment in gifted program students. Gifted Child Quarterly, 39(4), $236-244$. http://dx.doi.org/10.1177/001698629503900407

Parker, W. D. (1996). Psychological adjustment in mathematically gifted students. Gifted Child Quarterly, 40(3), 154-157. http://dx.doi.org/10.1177/001698629604000306

Piechowski, M. M. (1991). Emotional development and emotional giftedness. In N. Colangelo, \& G. A. Davis (Eds.), Handbook of gifted education (pp. 285-306). Boston, MA: Allyn \& Bacon.

Rimm, S. (2002). Peer pressures and social acceptance of gifted students. In M. Neihart, S. M. Reis, N. M. Robinson, \& S. M. Moon (Eds.), The social and emotional development of gifted children: What do we know? (pp. 13-18). Washington, DC: National Association for Gifted Children. 
Robinson, N. M. (2004). Effects of academic acceleration on the social-emotional status of gifted students. In N. Colangelo, S. M. Reis, S. G. Assouline, \& M. Gross (Eds.), A national deceived: Vol. 2 (pp. 59-68). Iowa City: IA: University of Iowa.

Sands, T., \& Howard-Hamilton, M. (1995). Understanding depression among gifted adolescent females: Feminist therapy strategies. Roeper Review, 17(3), 192-195. http://dx.doi.org/10.1080/02783199509553657

Sattler, J. M. (2008). Assessment of children: Cognitive foundations (5th ed.). San Diego, CA: Jerome Sattler Publisher, Inc.

Selye, H. (1978). The stress of life. New York, NY: McGraw-Hill.

Shaunessy, E., \& Suldo, S. M. (2010). Strategies used by intellectually gifted students to cope with stress during their participation in a high school International Baccalaureate program. Gifted Child Quarterly, 54(2), 127-137. http://dx.doi.org/10.1177/0016986209355977

Silverman, L. K. (Ed.). (1993). Counseling the gifted and talented. Denver, CO: Love Publishing.

Sousa, D. A. (2003). How the gifted brain learners. Thousand Oaks, CA: Corwin Press.

Sternberg, R. J., \& Davidson, J. E. (Eds.). (2005). Conceptions of giftedness. New York, NY: Cambridge University Press. http://dx.doi.org/10.1017/CBO9780511610455

Swiatek, M. A. (1995). An empirical investigation of the social coping strategies used by gifted adolescents. Gifted Child Quarterly, 39(3), 154-160. http://dx.doi.org/10.1177/001698629503900305

Swiatek, M. A. (2001). Social coping among gifted high school students and its relationship to self-concept. Journal of Youth and Adolescence, 30(1), 19-39. http://dx.doi.org/10.1023/A:1005268704144

Tannenbaum, A. J. (1983). Gifted Childen: Psychological and Educational Perspectives. New York, NY: McMillan.

Terman, L. M., \& Oden, M. H. (1925). Mental and physical traits of a thousand gifted children: Genetic Studies of Genius, Vols. 1 and 2. Stanford, CA: Stanford University Press.

Terman, L. M., \& Oden, M. H. (1935). The promise of Youth: Genetic Studies of Genius, Vol. 3. Stanford, CA: Stanford University Press.

Terman, L. M., \& Oden, M. H. (1947). The gifted child grows up: Genetic Studies of Genius, Vol. 4. Stanford, CA: Stanford University Press.

Tong, J., \& Yewchuk, C. (1996). Self-concept and sex-role orientation in gifted high school students. Gifted Child Quarterly, 40(1), 15-23. http://dx.doi.org/10.1177/001698629604000103

Yewchuck, C., \& Jobagy, S. (1991). Gifted adolescents at risk for suicide. European Journal for High Ability, 2, 73-85. http://dx.doi.org/10.1080/0937445910020109

\section{Copyrights}

Copyright for this article is retained by the author(s), with first publication rights granted to the journal.

This is an open-access article distributed under the terms and conditions of the Creative Commons Attribution license (http://creativecommons.org/licenses/by/3.0/). 